\title{
Perception of Importance of Premarital Counseling among Medical Students of Tanta University, Egypt
}

\author{
Ibrahim Ali Kabbash, Asmaa Omar Attalla, Salwa Abd Elmageed Atlam \\ Public Health \& Community Medicine-Faculty of Medicine- Tanta University \\ Received: July. $2018 \quad$ Accepted: September, 2018
}

\begin{abstract}
Background: In Egypt utilization of pre-marriage counseling and testing (PMC) is still limited. Objective: To identify knowledge and attitude of medical students towards PMC. Method: A cross sectional study at Tanta Faculty of Medicine on 379 students using a predesigned questionnaire. Results: The majority admit that PMC can detect hereditary diseases (79.4\%) and sexually transmitted infections (73.8\%). Among participants, 76.2\% were willing to use free PMC and $18.8 \%$ expressed awareness of premarital investigations. Only $49.7 \%$ knew about places providing PMC. Concerning level of information, $27.6 \%$ of participants did not have enough information about PMC. The main sources of information were mass media $(31.8 \%)$ and internet $(30.0 \%)$. The main reason for not utilizing PMC was not to interfere with "Allah will". More males (12.5\%) think that PMC may delay marriage as compared to $5.1 \%$ for females. Students with consanguineous parents showed significantly higher level of knowledge than those whose parents were not related. Conclusion: Students had good perception of the importance of PMC but they did not knew the places and investigations of PMC.
\end{abstract}

Key Words: Premarital Counseling, Medical students, Egypt

Corresponding author: Ibrahim Kabbash e-mail: iafkabbash@gmail.com, ibrahim.kabbash@med.tanta.edu.eg

\section{Introduction}

Premarital Counseling (PMC) involves a consultation through which history, medical examination as well as laboratory investigations done to personnel preparing for getting married, so as to detect any hereditary and transmissible diseases. Counseling before marriage can be a valuable and a very indispensable component of preventive medicine. ${ }^{1}$

Premarital genetic counseling reduces the probability of children that might be affected by a disorder, through defining the necessity of treatment (e.g. phenylketonuria) or helping the couple to make a decision whether or not avoiding conception in the presence of a high risk of abnormality. ${ }^{2}$ Genetic disorders occur in about $2 \%-5 \%$ of all live births, account for up to $30 \%$ of pediatric hospital admissions and cause about $50 \%$ of childhood deaths in industrialized countries. The issue of PMC is of immense significance to prevent congenital malformation in Arab Nations because of the high occurrence of consanguineous marriages. ${ }^{3}$

Studies reported that consanguinity rates among the Egyptians throughout the last 40 years ranges between $29 \%$ and $39 \%{ }^{4}$ Hearing impairment, mental retardation, 
autosomal recessive osteoporosis and blood disorders such as thalassemia are among diseases which may result from marriage among relatives and can be identified and prevented via premarital counseling. ${ }^{5,6}$ In addition, premarital exposure to some infectious diseases such as hepatitis B virus, and rubella during pregnancy which are simply prevented by premarital vaccination may result in physical or mental disorders in the newborn. ${ }^{7}$ In Egypt the first pre-marriage checkup center has been in service since mid-2001. Even though the attendants' number is still limited. It seems that many youthful couples are unconvinced about the worth of PMC. ${ }^{8}$

Medical students are the prospect health care providers, who are supposed to provide health services and convince their surrounding communities regarding the importance of preconception care and utilization of the available health services. Those students need to obtain more information on reproductive health including premarital counseling. ${ }^{9}$ As well they require additional encouragement to utilize premarital counseling services which should be an essential part of the primary health care services. ${ }^{10}$ Hence the objective of this study was to determine the perception of the importance of PMC and to identify some factors, which may influence its acceptance among medical students of Tanta University.

\section{Method}

Study settings: This study was conducted in Faculty of Medicine, Tanta University. The faculty recruited students from Lower Egypt governorates in the Nile Delta. There are nearly 600 students in each of the six academic grades of the faculty. These students will serve at primary health care and family health care units for two years after graduation.

Study design: a cross sectional study

Study participants: The target population of this study was students in the academic stage which extends for the first three years. The sample size was calculated using Epi-Info statistical software package created by World Health Organization and Center for Disease Prevention and Control (CDC), Atlanta, Georgia, USA in 2002. The sample size was calculated at $\mathrm{N}>369$ based on the following criteria: $95 \%$ confidence level, expected perception of $60 \%$ of optimal and a margin of error of $5 \%$.

In each academic year, students were divided into four subgroups for practical training (12 subgroups). Two groups were chosen randomly to be included in the study sample. The total number of students in the chosen clusters was 379 . The total number of returned full sheets was 340 representing response rate of $89.71 \%$.

Methods of data collection: The researchers used a predesigned questionnaire sheet for data collection. The questionnaire included socio-demographic data, knowledge and attitude of students towards premarital counseling and testing. The questionnaire included two questions asking if willing to marry a blood relative or a person with a hereditary diseases then 8 questions related to knowledge of premarital counseling. Knowledge questions were scored 1 for correct answers and 0 for incorrect answers with a total score ranging between 0-8.

The questionnaire was self-administered and data collectors were available during filling the questionnaire to respond to any questions from study participants. Only questionnaire sheets with full data were included in the study analysis. 
Table (1): Socio-demographic

characteristics of the studied students

\begin{tabular}{|c|c|c|}
\hline Variables & $\begin{array}{c}\text { No. } \\
(n=340)\end{array}$ & $\%$ \\
\hline $\begin{array}{l}\text { Age in years } \\
18- \\
20- \\
22-\end{array}$ & $\begin{array}{l}131 \\
179 \\
30\end{array}$ & $\begin{array}{l}38.5 \\
52.7 \\
8.8\end{array}$ \\
\hline $\begin{array}{l}\text { Gender } \\
\text { Males } \\
\text { Females }\end{array}$ & $\begin{array}{l}144 \\
196\end{array}$ & $\begin{array}{l}42.4 \\
57.6\end{array}$ \\
\hline $\begin{array}{l}\text { Residence } \\
\text { Urban } \\
\text { Rural }\end{array}$ & $\begin{array}{l}167 \\
173\end{array}$ & $\begin{array}{l}49.1 \\
50.9\end{array}$ \\
\hline $\begin{array}{l}\text { Marital status } \\
\text { Single } \\
\text { Engaged }\end{array}$ & $\begin{array}{l}331 \\
9\end{array}$ & $\begin{array}{l}97.4 \\
2.6\end{array}$ \\
\hline $\begin{array}{l}\text { Father's education } \\
\text { Illiterate } \\
\text { Primary } \\
\text { Secondary } \\
\text { University }\end{array}$ & $\begin{array}{l}6 \\
9 \\
61 \\
263 \\
\end{array}$ & $\begin{array}{l}2.1 \\
2.6 \\
17.9 \\
77.7\end{array}$ \\
\hline $\begin{array}{l}\text { Mother's education } \\
\text { Illiterate } \\
\text { Primary } \\
\text { Secondary } \\
\text { University }\end{array}$ & $\begin{array}{l}20 \\
11 \\
74 \\
235 \\
\end{array}$ & $\begin{array}{l}5.9 \\
3.2 \\
21.8 \\
69.1\end{array}$ \\
\hline $\begin{array}{l}\text { Father's job } \\
\text { Unemployed } \\
\text { Non skilled manual worker } \\
\text { Skilled manual worker } \\
\text { Employee } \\
\text { Professional }\end{array}$ & $\begin{array}{l}7 \\
4 \\
31 \\
88 \\
210\end{array}$ & $\begin{array}{l}2.1 \\
1.2 \\
9.1 \\
25.9 \\
61.8\end{array}$ \\
\hline $\begin{array}{l}\text { Mother's job } \\
\text { Housewife } \\
\text { Non skilled manual worker } \\
\text { Skilled manual worker } \\
\text { Employee } \\
\text { Professional }\end{array}$ & $\begin{array}{l}140 \\
0 \\
1 \\
37 \\
162\end{array}$ & $\begin{array}{l}41.1 \\
0.0 \\
0.3 \\
10.9 \\
47.7\end{array}$ \\
\hline $\begin{array}{l}\text { Family size: } \\
<5 \\
5 \\
6 \\
7 \\
8 \pm+ \\
\text { Not reported }\end{array}$ & $\begin{array}{l}36 \\
\mathbf{1 1 9} \\
98 \\
50 \\
11 \\
26\end{array}$ & $\begin{array}{l}10.6 \\
\mathbf{3 5 . 0} \\
28.8 \\
14.8 \\
3.2 \\
7.6\end{array}$ \\
\hline $\begin{array}{l}\text { Parents consanguinity } \\
\text { Not related } \\
\text { Cousins } \\
\text { Far relatives }\end{array}$ & $\begin{array}{l}276 \\
46 \\
18\end{array}$ & $\begin{array}{l}81.2 \\
13.5 \\
5.3\end{array}$ \\
\hline $\begin{array}{l}\text { Family history of } \\
\text { hereditary diseases }\end{array}$ & 64 & 18.8 \\
\hline
\end{tabular}

\section{Statistical analysis:}

The collected data were organized, tabulated using SPSS version 19 (Statistical Package for Social Studies) created by IBM, Illinois, Chicago, USA. The numbers and percentages were calculated for each subcategories of studied variable. The differences between subcategories were tested using chi square test. When chi square was not found appropriate, Fisher exact test was used. For the total score, the mean and standard deviation were calculated and differences between subcategories were tested using student's t test. The level of significance was adopted at $\mathrm{p}<0.05$.

\section{Ethical considerations}

The study was approved by the internal review board of Tanta Faculty of Medicine.

Data were collected anonymously and confidentiality was ensured during the whole period of the study

Before data collection the objectives of the study and the content of the questionnaire sheet were discussed with study participants and their verbal consent was obtained.

\section{Results}

The total number of participant in the present study was 340 . Among participants age 20 years represented $52.7 \%$. Males represented $42.4 \%$. Participants were equally distributed in urban and rural residence (49.1\% and $50.9 \%$, respectively). The majority were of single marital status (97.4\%). Concerning parents educations, the majority had parents of university education as presented by $77.7 \%$ for fathers and $69.1 \%$ for mothers. Participants whose fathers occupied a professional job represented $61.8 \%$ and $47.7 \%$ of their mothers were also professional while $41.1 \%$ had housewife mothers. The family size ranging 5-7 represented $63.8 \%$. 
Among $81.2 \%$ of participants, parents were not related and $18.8 \%$ reported family history of hereditary diseases (Table 1)

Concerning perception of premarital counseling, only $6.2 \%$ of participants were willing to get married to a blood relative. This observation was significantly higher among males $(9.7 \%)$ compared to females $(3.6 \%)$. On the other hand $18.5 \%$ were willing to marry a person with known hereditary disease which was significantly higher among males (23.6\%) compared to females (14.8\%). The majority of participants agreed that premarital counseling and testing can detect hereditary diseases $(79.4 \%)$ and sexually transmitted infections (73.8\%). Meanwhile less than one half (42.4) knew that hepatitis B can be transmitted sexually. Among participants, $76.2 \%$ were willing to use free premarital counseling. Differences between males and females were not statistically significant. (Table 2)

Few of participants express their awareness of premarital investigations $(18.8 \%)$. Awareness of these investigations was reported by $27.1 \%$ of males which was significantly higher than $12.8 \%$ among females. The majority of participants reported knowing about sexually transmitted infections (90.3\%), and how to delay pregnancy in early marriage (80.3\%). Only $49.7 \%$ knew about places providing premarital counseling and testing with no significant differences in relation to gender. (Table 2)

Concerning level and source of information, $27.6 \%$ of study participants expressed that they did not have enough information about premarital counseling and testing. The main sources of information were $\mathrm{TV}$ and radio $(31.8 \%)$, internet $930.0 \%$ ) and relatives $(20.0 \%)$. Significantly more females $(32.7 \%)$ reported haven't enough information as compared to males (20.8\%). Internet and friends $(47.9 \%$ and $17.4 \%)$ were significantly more reported as sources of information for premarital counseling as compared to females who reported internet as the source of information by $16.8 \%$ and friends among $5.1 \%$. (Table 3 )

Concerning reasons for not utilizing premarital services, the desire not to interfere with "Allah will" was reported by $12.4 \%$ and was the most frequent reason of non-utilization. Significantly more males think that premarital counseling and testing may delay marriage $(12.5 \%)$ as compared to only $5.1 \%$ for females. Those who will not utilize the services for being afraid of results of premarital counseling and testing represented $8.5 \%$ with nearly equal percentages for both gender. Only $0.9 \%$ mentioned that premarital counseling is not important and that financial constraints may affect its utilization. (Table 4)

The study participant had a good score of more than 5/8. Gender, residence, parents' educational levels or their jobs had no significant difference on the mean score of knowledge among studied participants. The same observation was found for family size and familial history of hereditary disease. The only statistically significant difference was observed due to consanguinity of parents. Students who had consanguineous parents showed significantly higher level of knowledge total score of $5.62 \pm 1.28$ compared to $5.17 \pm 1.70$ for those whose parents were not related. (Table 5)

\section{Discussion}

PMC is a primary preventive approach for couples before marriage to optimize women's wellness and subsequent pregnancy outcomes. $^{11}$ Many young women and men need more information on 
Table (2): Distribution of studied students in relation to their perception of premarital counseling and testing

\begin{tabular}{|c|c|c|c|c|c|c|c|c|}
\hline \multirow{2}{*}{ Variables } & \multicolumn{2}{|c|}{ Males $(n=144)$} & \multicolumn{2}{|c|}{ Female $(n=196)$} & \multicolumn{2}{|c|}{ Total $(n=340)$} & \multirow{2}{*}{$X^{2}$} & \multirow{2}{*}{$\mathbf{p}$} \\
\hline & n & $\%$ & n & $\%$ & n & $\%$ & & \\
\hline $\begin{array}{l}\text { Willing to marry a } \\
\text { blood relative }\end{array}$ & 14 & 9.7 & 7 & 3.6 & 21 & 6.2 & 5.419 & $0.020 *$ \\
\hline $\begin{array}{l}\text { Willing to marry a } \\
\text { person with known } \\
\text { hereditary disease }\end{array}$ & 34 & 23.6 & 29 & 14.8 & 63 & 18.5 & 4.273 & $0.039 *$ \\
\hline $\begin{array}{l}\text { Premarital counseling } \\
\text { and testing can detect } \\
\text { hereditary diseases }\end{array}$ & 118 & 81.9 & 152 & 77.6 & 270 & 79.4 & 0.980 & 0.322 \\
\hline $\begin{array}{l}\text { STIs can be } \\
\text { and treated } \\
\text { marriage }\end{array}$ & 109 & 75.7 & 142 & 72.4 & 251 & 73.8 & 0.452 & 0.501 \\
\hline $\begin{array}{l}\text { Willing to utilize free } \\
\text { premarital counseling }\end{array}$ & 107 & 74.3 & 152 & 77.6 & 259 & 76.2 & 0.482 & 0.488 \\
\hline $\begin{array}{l}\text { Knowing premarital } \\
\text { investigations }\end{array}$ & 39 & 27.1 & 25 & 12.8 & 64 & 18.8 & 11.135 & $0.001 *$ \\
\hline $\begin{array}{lr}\text { Knowing } & \text { places } \\
\text { providing premarital } & \text { premseling and testing }\end{array}$ & 80 & 55.6 & 89 & 45.4 & 169 & 49.7 & 3.419 & 0.064 \\
\hline $\begin{array}{l}\text { Hepatitis B can be } \\
\text { transmitted sexually }\end{array}$ & 64 & 44.4 & 80 & 40.8 & 144 & 42.4 & 0.448 & 0.504 \\
\hline $\begin{array}{l}\text { Knowing } r \text { about } \\
\text { sexually transmitted } \\
\text { infections (STIs) }\end{array}$ & 128 & 88.9 & 179 & 91.3 & 307 & 90.3 & 0.563 & 0.452 \\
\hline $\begin{array}{l}\text { Knowing how to delay } \\
\text { pregnancy in early } \\
\text { marriage }\end{array}$ & 115 & 79.9 & 158 & 80.6 & 273 & 80.3 & 0.030 & 0.863 \\
\hline
\end{tabular}

*Significant

reproductive health and access to services before they have their first child. ${ }^{12}$

In the present study, the participants had a good score of knowledge regarding PMC. The majority of them reported knowing about STI and how to delay pregnancy in early marriage. Nearly half of them know places providing premarital counseling and testing, while few of them were aware of premarital investigations. This is due to participants' young age where they lack the awareness of the seriousness of genetic and hereditary disorders and ignorance about where to seek care. Many studies in Egypt, Syria, and Saudi Arabia proved that most of study participants were aware of the presence of PMC services. ${ }^{10,13,14}$
AL Kindi et al., in his study of knowledge and attitude of university students towards premarital screening program in Oman proved that most of participants $(73.9 \%)$ heard about PMCS (Premarital carrier screening), but half of them were unaware of premarital testing. The knowledge about what tests does PMS include revealed that $33 \%$ of the participants thought it includes blood tests alone, 32\% thought it includes blood tests and physical examination, while $35 \%$ did not know the answer. On testing the knowledge about the diseases that are targeted by PMS, 66\% thought that PMS targets genetic blood disorders as well as sexually transmitted diseases, 25\% thought that PMS targets genetic blood 
Table (3): Distribution of studied students in relation to their sources of information regarding premarital counseling and testing

\begin{tabular}{|c|c|c|c|c|c|c|c|c|}
\hline \multirow[t]{2}{*}{ Source of information } & \multicolumn{2}{|c|}{$\begin{array}{l}\text { Males } \\
(n=144)\end{array}$} & \multicolumn{2}{|c|}{$\begin{array}{l}\text { Female } \\
(n=196)\end{array}$} & \multicolumn{2}{|c|}{$\begin{array}{l}\text { Total } \\
(n=340)\end{array}$} & \multirow[t]{2}{*}{$X^{2}$} & \multirow[t]{2}{*}{$\mathbf{p}$} \\
\hline & $\mathbf{n}$ & $\%$ & n & $\%$ & n & $\%$ & & \\
\hline Have no enough information & 30 & 20.8 & 64 & 32.7 & 94 & 27.6 & 5.798 & $0.016^{*}$ \\
\hline TV/Radio & 39 & 27.1 & 69 & 35.2 & 108 & 31.8 & 2.526 & 0.112 \\
\hline Magazines/Books & 22 & 15.3 & 31 & 15.8 & 53 & 15.6 & 0.018 & 0.892 \\
\hline Internet & 69 & 47.9 & 33 & 16.8 & 102 & 30.0 & 38.184 & $0.001 *$ \\
\hline Friends & 25 & 17.4 & 10 & 5.1 & 35 & 10.3 & 13.510 & $0.001 *$ \\
\hline Relatives & 23 & 16.0 & 45 & 23.0 & 68 & 20.0 & 2.533 & 0.112 \\
\hline
\end{tabular}

*Significant

Table (4): Distribution of studied students in relation to their reasons for not utilizing premarital counseling and testing

\begin{tabular}{|c|c|c|c|c|c|c|c|c|}
\hline \multirow{2}{*}{$\begin{array}{l}\text { Reasons for not utilizing } \\
\text { premarital counseling and } \\
\text { testing }\end{array}$} & \multicolumn{2}{|c|}{$\begin{array}{c}\text { Males } \\
(n=144)\end{array}$} & \multicolumn{2}{|c|}{$\begin{array}{l}\text { Female } \\
(n=196)\end{array}$} & \multicolumn{2}{|c|}{$\begin{array}{c}\text { Total } \\
(n=340)\end{array}$} & \multirow[t]{2}{*}{$X^{2}$} & \multirow[t]{2}{*}{$\mathbf{p}$} \\
\hline & $\mathbf{n}$ & $\%$ & $\mathbf{n}$ & $\%$ & $\mathbf{n}$ & $\%$ & & \\
\hline Not important & 2 & 1.4 & 1 & 0.5 & 3 & 0.9 & FE & 0.576 \\
\hline Have no time & 6 & 4.2 & 6 & 3.1 & 12 & 3.5 & 0.298 & 0.858 \\
\hline Afraid of results & 12 & 8.3 & 17 & 8.7 & 29 & 8.5 & 0.012 & 0.912 \\
\hline Financial constraints & 3 & 2.1 & 0 & 0.0 & 3 & 0.9 & $\mathrm{FE}$ & 0.075 \\
\hline May delay marriage & 18 & 12.5 & 10 & 5.1 & 28 & 8.2 & 6.012 & $0.014 *$ \\
\hline Not to interfere with Allah will & 20 & 13.9 & 22 & 11.2 & 42 & 12.4 & 0.544 & 0.461 \\
\hline
\end{tabular}

*Significant $F E=$ Fisher exact test

disorders alone, $3 \%$ thought that it targets sexually transmitted diseases alone and the rest $(6 \%)$ did not know the answer. ${ }^{15}$

AL Sulaiman et al., in Saudi Arabia found that the study participants had a good knowledge about the PMC testes, 91\% of them knew that blood testing is done for couples and $94 \%$ of them knew that genetic disorders were the target for conducting the test. ${ }^{16}$ Low knowledge level (43.6\%) was detected by Eshra et al., in Egypt as their participants were villagers most of them were illiterates, while our participants were students. ${ }^{17}$ Lack of knowledge was also reported by Sobhy et al.,and Inandi et al., in their studies involving Egyptian nurses and Turkish university students. These differences also explained by the differences in education level of study participants. ${ }^{18,19}$

In the present study, there was no statistical significant difference between males and females regarding the mean score of perception regarding PMC, while males showed significantly higher percentage than females regarding awareness of premarital investigations. This may be attributed to the more contact of males to the community than females, and it may be considered stigma especially for females in our country to ask about issues related to marriage and sexuality. In United Arab Emirates, Ganczak et al., found that males scored higher on knowledge than their female counterparts. [20] Also AL-Farsi et al., in Oman reported that males appeared to be more aware of PMCS and its existence in their region. ${ }^{21}$

On the other hand, Farahat et al., in their study in Menoufiya University, showed that female students had more knowledge than males. ${ }^{10}$ This results was in accordance with that found by Aama et al., in Saudi Arabia. ${ }^{22}$ A study in Nigeria found that women tend to have more knowledge about issues relating to 
reproductive and sexual health than their male counterparts. ${ }^{23}$ Similar studies such as those by Khater and El Ghazaly and Abd Al-Azeem et al., demonstrated that women were more oriented and more knowledgeable with important health issues related to premarital genetic screening than men which reflected on their better attitude. ${ }^{8,24}$

Concerning level and source of information about PMC, the present study results were in agreement with those proved by Farahat et al., who found that, media was the most frequent source of knowledge among Menoufia students followed by friends and relatives. ${ }^{10}$

Ibrahim et al., in Saudi Arabia and ALKindi et al., in Oman in their studies reported that family and friends were the main sources of knowledge of their participants regarding PMC followed by media. $^{14,15}$ On the other hand AL-Farsi et al., in proved that the main source of knowledge about PMC was information from health workers, followed by periodical notes and the friends. Media and school were not found to be an important source of information. $^{21}$

In the present study, the participants had a good score of attitude regarding PMC, the majority of students were willing to use free premarital counseling and the majority of them agreed that premarital counseling and testing can detect hereditary diseases and sexually transmitted infections. However, only $6.2 \%$ of participants were willing to get married to a blood relative. This observation was significantly higher among males compared to females .This may attributed to the awareness of students to the risk of transmission of hereditary diseases by consanguinity.

In the present study $18.5 \%$ of students were willing to marry a person with known hereditary disease which was significantly higher among males (23.6\%) compared to females $(14.8 \%)$. This was in accordance with the study of AL-Farsi et al., in Oman who proved that $15.3 \%$ of the study participants decided to get married even in case of incompatible results. Also, 22.3\% of them refused to change their decisions despite both couples being carrier of the same disorder and this may be to avoid social problems and breakdown of the family relationships. This reflected the need to improve the policies at PHC units. $^{21}$

AL Kindi et al., in his study of knowledge and attitude of university students towards premarital screening program in Oman proved that the participants' attitudes towards PMS were favorable, where the majority believed that PMS is important and agreed to carry it out in the future. The majority of the participants reported that they will perform PMS to prevent transmission of diseases to their children. This reflects that the participants had a good understanding of the preventive value of PMS. ${ }^{15}$ The same results has been reported in other Arab countries. ${ }^{17,22,25}$

AL Kindi et al., reported that about half of the participants agreed making PMS as an obligatory procedure before marriage ,but around one-third of them favored putting laws and regulations in place to prevent marriage in case of positive results. ${ }^{15}$ This is lower than what was found in Saudi Arabia where $85 \%$ agreed on making PMS as a mandatory procedure before marriage and $63 \%$ agreed on legal interference in case of positive results. ${ }^{25}$ These choices due to high rate of consanguineous marriages among the Omani population; in which PMS might create some social annoyance and break the autonomous of the family. This attitude could be improved by intense health education especially for 
those at high risk of transmitting genetic disorders.

Table (5): Factors affecting total perception score

\begin{tabular}{|c|c|c|c|}
\hline Variables & Mean \pm SD & $t$ & p \\
\hline $\begin{array}{l}\text { Gender } \\
\text { Males } \\
\text { Females } \\
\end{array}$ & $\begin{array}{l}5.40 \pm 1.83 \\
5.15 \pm 1.47\end{array}$ & 1.340 & 0.182 \\
\hline $\begin{array}{l}\text { Residence } \\
\text { Urban } \\
\text { Rural }\end{array}$ & $\begin{array}{l}5.37 \pm 1.62 \\
5.14 \pm 1.64\end{array}$ & 1.247 & 0.213 \\
\hline $\begin{array}{l}\text { Father' } \\
\text { education } \\
\text { Below } \\
\text { university } \\
\text { University }\end{array}$ & $\begin{array}{l}5.10 \pm 1.56 \\
5.30 \pm 1.65\end{array}$ & 0.910 & 0.363 \\
\hline $\begin{array}{l}\text { Mothers' } \\
\text { education } \\
\text { Below } \\
\text { university } \\
\text { University } \\
\end{array}$ & $\begin{array}{l}5.20 \pm 1.53 \\
5.28 \pm 1.68\end{array}$ & 0.399 & 0.690 \\
\hline $\begin{array}{l}\text { Fathers' job } \\
\text { Professional } \\
\text { Others }\end{array}$ & $\begin{array}{l}5.38 \pm 1.65 \\
5.05+1.59\end{array}$ & 1.774 & 0.077 \\
\hline $\begin{array}{l}\text { Mothers' job } \\
\text { Housewives } \\
\text { Working }\end{array}$ & $\begin{array}{l}5.26 \pm 1.60 \\
5.24 \pm 1.66\end{array}$ & 0.107 & 0.915 \\
\hline $\begin{array}{l}\text { Family size } \\
\leq 5 \\
>5\end{array}$ & $\begin{array}{l}5.35 \pm 1.81 \\
5.17 \pm 1.47\end{array}$ & 0.969 & 0.333 \\
\hline $\begin{array}{l}\text { Parents } \\
\text { consanguinity } \\
\text { Not related } \\
\text { Related }\end{array}$ & $\begin{array}{l}5.17 \pm 1.70 \\
5.62 \pm 1.28\end{array}$ & 2.032 & $0.043^{*}$ \\
\hline $\begin{array}{l}\text { Familial } \\
\text { hereditary } \\
\text { disease } \\
\text { Negative } \\
\text { Positive }\end{array}$ & $\begin{array}{l}5.25+1.69 \\
5.28+1.40\end{array}$ & 0.154 & 0.878 \\
\hline
\end{tabular}

*Significant

Also Farahat et al., proved that, participants' attitudes toward PMC were favorable $(53.9 \%) .{ }^{10}$

This agreed with the study by Ibrahim et al., who found that the majority of participants agreed on the importance of PMC $(82.3 \%){ }^{14}$ In addition, an educational program conducted among female students in King Saud University, Riyadh found that students' attitude was positive $(81.8 \%$ of students in the pretest and $85.9 \%$ in the post-test approved the importance of PMC). ${ }^{26}$

A study conducted among nursing students in Alexandria University showed that $65.5 \%$ of them had a positive attitude toward premarital counseling. ${ }^{18}$ This is similar to what has been reported in many studies such as those by Al- Kahtani ${ }^{25}$, AlAama et al., ${ }^{26}$ and Al-Kindi. ${ }^{15}$ In contrast, a Syrian study reported that, although students had some positive attitude, they still had negative attitude and perceptions toward other aspects of PMC, this may be due to poor information of students regarding PMC. ${ }^{13}$

Concerning reasons for not utilizing premarital services, the desire not to interfere in "Allah will" was the most frequent reason of non-utilization. Significantly more males think that premarital counseling and testing may delay marriage as compared to females. Those who refrained from using premarital counseling and tests for being afraid of test results came second. This may be due to misunderstanding of Islamic rules, lack of experience in social negotiation, ignorance about where to seek care, social stigma, and poor treatment by service providers which limit young people's access to the services they need

AL-Farsi et al., in Oman reported that, nearly one third of participants did not accept PM testing. The causes behind this negative attitude were lack of awareness of the importance of PMC, lack of PMC centers, loss of interest, lack of hereditary diseases in the family, or no relationship with partner. ${ }^{21}$

There is a great need to focus on the target population, mainly unmarried young adults such as university students because their 
beliefs and attitudes will not only affect their choices in life including their choice on a partner but will also affect convincing their surrounding community about the importance of PMC as medical care providers..

\section{Conclusion}

Although most of the students have a good perception of the importance of PMC, less than half of them knew the places of PMC places and were not aware of premarital investigations. The main sources of information for students about PMC were mass media and internet. The most frequent reason of non-utilization of PMC services is the desire not to interfere in "Allah will". The results of this study reflect the importance of health education programs in schools, faculties and through media for improving knowledge, attitude and utilization of PMC.

\section{References}

1. Ministry of Health and Population [MOHP]. Standards of practice for integrated $\mathrm{MCH} / \mathrm{RH}$ services 1st ed. (2005). Available at: http://www.drguide.mohp.gov.eg./newsite/Elearning.

2. Cassens BJ. Preventive medicine and public health. Epidemiology, and prevention of selected acute illnesses. 2nd ed. USA: Williams \& Wilkins, 1992.

3. Ahmed S (2010). Risk reduction of genetic disorders by pre-marital and neonatal screening. Eastern Bioethics and Life Sciences. Dubai, UAE. Retrieved May 20th, 2011 from http://www.lifesciencesmagazines.com 4. Khayat RG, Saxena PC. Consanguinity and its effect on infant and childhood mortality in Egypt, iussp 2005.princeton.edu/download.aspx.

5. Kasim A, Adnan A. Risk factors of mental retardation in children attending an educationally subnormal/mental school in
Dammam, Saudi Arabia. Annals of Saudi Medicine 1993; 13(4):355-9.

6. Alwan AS Hamamy H. Hereditary disorders in the Eastern Mediterranean Region of World Health Organisation. Proceedings of the symposium on the medical genetics in the setting of Middle Eastern population. Riyadh: King Abdulaziz City for Science and Technology, 1993.

7. El-Hazmi MA. Genetic diseases in Saudi Arabia: A model for national awareness and care programme. Saudi Medical Journal 1992; 13(6): 514-20.

8. Khater TR \& El-Ghazaly Harb,S. Premarriage checkup Egypt. MBJ, 2003; 4(2):210-15

9. Chuaung $\mathrm{CH}$, Chen PC. Preconception car e. Are Primary Care Residents Adequately Prepared To Care for Women of Reproductive Age? Fam. Plann. Perspect, (2008): 27(2).

10. Farahat TM , Hala Elmoselhy S., Shaheen HM, Mohamed HM, Mohaseb MM: Knowledge and attitude of students in Menoufia University, Shebin Elkom city toward premarital care in 2012. Menoufia Medical Journal. 2014; 27:347-352. DOI: 10.4103/1110-2098.141706

11. Agrey N, Crowe KM, Levitt C, MacDonald J, MacLean D, Polomeno V. Hanvey L editor. Preconception care in family centered maternity and newborn care. National guidelines. Ottawa: Health Canada, Minister of Public Works and Government Services; 2005. 301-329

12. Moos MK. Preconceptional health promotion: progress in changing a prevention paradigm. J Perinat Neonatal Nurs 2004; $18: 12-15$

13. Gharaibeh H, Mater FK. Young Syrian adults' knowledge, perceptions and attitudes to premarital testing. Int Nurs Rev 2009; 56:450 455.

14. Ibrahim NKR, Al-Bar H, Al-Fakeeh A, Al-Ahmadi J, Qadi M, Al-Bar A, Milaat W. An educational programme about pre-marital screening for unmarried female students in King Abdul-Aziz University, Jeddah. J Infect Public Health 2012. Available at: http://www.elsevier. com/locate/jiph. [Last accessed on 2012 Apr 3].
Vol. 37
April

2019 
15. Al-Kindi R, Al-rujaibi S, Al-Kendi M. Knowledge and attitude of university students towards premarital screening program. Oman Med J 2012; 7:291-296.

16. AL Sulaiman A, Suliman A, AL Mishaari M, AL Sawadi A, Owaidah TM. Knowledge and attitude toward the hemoglobinopathies premarital screening program in Saudi Arabia: Population-based survey. Hemoglobin.2008, 32: $531-538$.

17. Eshra DK, Dongham LS, El-Sherbini AF. Knowledge and attitude towards premarital counseling and examination. J Egypt Public Health Assoc 1989; 64:1-5.

18. Sobhy SI, Shoeib FM, Zaki NH. Assessment and upgrading of Alexandria University nursing students' knowledge and attitude about genetic counseling. J Egypt Public Health Assoc 2001; 76:205-222.

19.19. Inandi $\mathrm{T}$, Tosun A, Guraksin A. Reproductive health: knowledge and opinions of university students in Erzurum, Turkey Eur J Contracept Reprod Health Care 2003; 8:177184.

20. Ganczak M, Barss P, Alfaresi F, Almazrouei S, Muraddad A, Al-Maskari F. Break the silence: 'HIV/AIDS knowledge, attitudes, and educational needs among Arab University students in United Arab Emirates'. J Adolesc Health 2007; 40:572e1-572e8. Available at: http://www.sciencedirect. com/science/article/

21. AL-Farsi OA, AL-Farsi YM, Ouhtit A, AL-Farsi KH S, AL-Adawi S. A study on knowledge, attitude, and practice towards premarital carrier screening among adults attending primary healthcare centers in a region in Oman. BioMed Central Public Health 2014 14:380.

22. Al-Aama J, Al-Nabulsi B, Alyousef M, Asiri N, Al-Blewi S. Knowledge regarding the national premarital screening program among university students in western Saudi Arabia. Saudi Med J 2008; 11:1649-1653.

23. Arulogun OS, Adefioye OA. Attitude towards mandatory pre-marital HIV testing among unmarried youths in Ibadan Northwest Local Government Area, Nigeria. Afr J Reprod Health 2010. Available at: www.ajol.info/ index.php/ajrh/article/view/55781/44243. [Last accessed on 2011 Jun10].

24. Abd Al-Azeem ST, Elsayed ET, ElSherbiny NA, Ahmed LA. Promotion of knowledge and attitude towards premarital care: an interventional study among medical student in Fayoum University 2011. Journal of Public Health and Epidemiology Vol. 3(3), pp. 121-128, March 2011 Available online at http://www.academicjournals.org/jphe ISSN 2141-2316 (C2011 Academic Journals Available at: http:// www.academicjournals.org/jphe. [Last accessed on 2011 Jun 10].

25. AL-Khtani NH. Acceptance of premarital health counseling in Riyadh city, J Family Counseling Medicine 2000; 7:27-34. (PubMed)

26. Al-Aama JY. Perception of female students of King Saud University towards premarital screening. J Family Community Med 2006; 13:83-88. 